\title{
E.A. Григорьева
}

Кафедра анатомии человека, оперативной хирургии и топографической анатомии (зав. - проф. Н.А. Волошин) Запорожский государственный медииинский университет

\section{ИСПОЛЬЗОВАНИЕ ЛЕКТИНОВОЙ ГИСТОХИМИИИ ДЛЯ ИЗУЧЕНИЯ МОРФОЛОГИИ ЭПИТЕЛИОРЕТИКУЛОЦИТОВ ТИМУСА}

\begin{abstract}
ВИКОРИСТАННЯ ЛЕКТИНОВОЇ ГІСТОХІМІЇ ДЛЯ ВИВЧЕННЯ МОРФОЛОГІЇ ЕПІТЕЛІОРЕТИКУЛОЦИТІВ ТИМУСА

Резюме. У роботі вивчено розподіл WGA+ - епітеліоретикулоцитів у кірковій та мозковій речовині тимуса новонароджених щурів. Встановлено, що вміст WGA+ -епітеліоретикулоцитів кіркової та мозкової речовин динамічно змінюється протягом усього періоду спостереження. Максимальний вміст

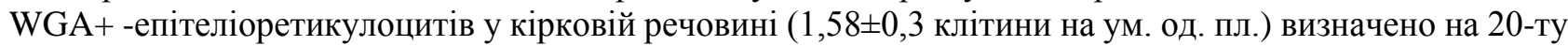
годину після народження, в мозковій речовині $(3 \pm 0,33$ клітини на ум. од. пл.) - на 2-гу годину постнатального життя. Протягом першого тижня після народження змінюється щільність розподілу рецепторів до лектину зародків пшениці на мембранах та у складі внутрішньоцитоплазматичних включень епітеліоретикулоцитів тимуса. Максимальна щільність розподілу рецепторів визначена на другу годину після народження.
\end{abstract}

Ключові слова: тимус, епітеліоретикулоцити, кіркова речовина, мозкова речовина, лектин зародків пшениці.

Эпителиоретикулоциты тимуса играют ключевую роль в селекции и развитии Т-лимфоцитов [1]. Взаимодействие между Т-лимфоцитами и эпителиоретикулоцитами тимуса опосредуется многочисленными адгезивными молекулами, включающими представителей суперсемейств интегринов и иммуноглобулинов. Эпителиоретикулоциты тимуса секретируют эндогенный лектин - галектин1 , который, связываясь с олигосахаридными лигандами клеточной мембраны тимоцитов и лимфобластов, опосредует адгезию незрелых тимоцитов к эпителиальным клеткам тимуса [2]. Галектин-1 вызывает апоптоз незрелых тимоцитов [3, 4]. Галектн-1 синтезируется эпителиоретикулоцитами преимущественно субкапсулярной зоны и коркового вещества тимуса. Концевым остатком галектина-1 является $\mathrm{N}$-ацетилглюкозамин, который, в свою очередь, специфичен для лектина завязи пшеницы, т.е. $\mathrm{WGA}^{+}$-эпителиоретикулоциты - это клетки, синтезирующие галектин-1.

Сиалирование поверхности Т-лимфоцитов изменяется на протяжении внутритимической дифференцировки. Синтез сиаловых кислот осуществляется не тимоцитами, а клетками тимического микроокружения, преимущественно эпителиоретикулоцитами [5]. Сиаловая кислота, сосредоточенная внутри цитоплазмы эпителиоретику- лоцитов мозгового вещества, позволяет выявлять эти клетки с помощью лектина завязи пшеницы.

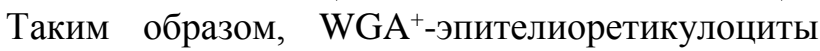
коркового вещества и субкапсулярной зоны тимуса содержат преимущественно концевые остатки $\mathrm{N}$-ацетилглюкозамина, и в меньшем количестве концевые остатки нейраминовой (сиаловой) кислоты, a $\mathrm{WGA}^{+}$-эпителиоретикулоциты мозгового вещества - преимущественно концевые остатки нейраминовой (сиаловой) кислоты. Увеличение накопления бензидиновой метки к лектину завязи пшеницы в корковом веществе свидетельствует об активации процессов внутритимической дифференцировки (положительной селекции тимоцитов), а накопление бензидиновой метки в цитоплазме эпителиоретикулоцитов мозгового вещества отражает процессы подготовки к эмиграции тимоцитов на периферию.

Цель иследования: изучить распределение рецепторов к лектину завязи пшеницы на эпителиоретикулоцитах тимуса новорожденных крыс.

Материалы и методы. Изучено 173 тимуса бельхх крыс линии Вистар от момента рождения до 7-х суток постнатальной жизни. Крыс содержали в соответствии с рекомендаџиями И.П. Западнюк и др. (1983). При работе с экспериментальными животными руководствовались тре-

(C) Григор'єва Е.А., 2016 
бованиям «Европейской конвенциии по защчите позвоночных животных, которые используются в экспериментальных и других научных целях» (Страсбург, 18.03.86). Уход за животныли осуществляли в соответствии с нормами и требованиями, разработанных согласно кодексу Совета Международных медицинских организаций «Международные рекомендации для проведения медико-биологических исследований с использованием животных».

С изелью более полного описания особенностей морфологии тимуса в самом напряженном раннем постнатальном периоде онтогенеза новорожденных животных под эфирным наркозом выводили из эксперимента с интервалом в 2 часа, начиная от момента рождения в течение первых 12 часов жизни, в дальнейшем - с интервалом в 4 часа до 48 часа после рождения, с интервалом в 6 часов на протяжении третьих суток жизни, $u$ с интервалом в 12 часов - до кониа первой недели после рождения.

Забор тимусов крыс осуществляли сразу после выведения животных из эксперимента: быстро, минимально касаясь органов, чтобы избежать артефактов в паренхиме. Для гистологического и гистохимического исследований тимус крыс фиксировали в жидкости Буэна. Кусочки обезвоживали в восходящей батарее спиртов. В качестве промежуточной среды применяли хлороформ. Кусочки заливали в смесь парафина, воска и каучука (20:1:1). В блоке тимуса ориентировали апикальной поверхностью к плоскости микротомного ножа, из блока изготавливали 150-200 серийных срезов толщчиной 5-6 мкм.

Производили изучение динамики структур тимуса, имеюших рецепторы к лектину завязей пшеницы по стандартной методике, описанной с использованием стандартных наборов "Лектины". Обработку срезов производили коньюгатом лектина завязей пшениць-пероксидаза хрена (WGA-HRP) в течение 2 часов при комнатной температуре в темноте после предварительной инактивации эндогенной пероксидазы. Морфометрический учет клеток, имеющих на своей поверхности пигментную бензидиновую метку конъюгатов лектина завязей пшениць $W G A^{+}$, прочзводили при помощуи окулярной сетки на условной единище площзади 1430 мкм ${ }^{2}$ при иммерсионном увеличении микроскопа (х900). Морфометрические показатели получены с использованием способа количественного учета С.Б. Стефанова. Все числовые результаты обрабатывали методами вариационной статистики с использованием таблиц С.Б. Стрелкова (1980) с учетом индивидуальной изменчивости. Сравнение средних величин проводили по показателям критерия
Фишера-Стъюдента. Различия двух средних считали достоверными при $p<0,05$.

Результаты исследований и их обсуждение. углеводные остатки N-ацетил-Dглюкозамина и сиаловой кислоты, являющиеся рецепторами к лектину завязи пшеницы (WGA) в ткани тимуса новорожденных крыс, выявляются на мембране и в цитоплазме эпителиоретикулоцитов, единичных лимфоцитах, люминальной поверхности сосудов, в капсуле и соединительнотканных перегородках органа, гранулах тучных клеток. Бензидиновая метка к лектину завязей пшеницы распределена в ткани тимуса равномерно, наименьшая плотность распределения наблюдается в субкапсулярной зоне, наиболее интенсивно окрашены структуры кортико-медуллярной границы и мозгового вещества. В ткани тимуса встречаются единичные эпителиоретикулоциты, в цитоплазме которых определяются $\mathrm{WGA}^{+}$-включения.

рецепторы к лектину завязи пшеницы (WGA) в ткани тимуса новорожденных крыс выявляются на мембране и в цитоплазме эпителиоретикулоцитов коркового и мозгового вещества. Выявление рецепторов к лектину завязи пшеницы подчеркивает различную морфологию эпителиальных клеток этих морфофункциональных зон. тонкие отростки эпителиоретикулоцитов коркового вещества и субкапсулярной зоны образуют нежную мелкопетлистую сеть. В мозговом веществе отростки $\mathrm{WGA}^{+}$эпителиоретикулоцитов короткие, утолщенные. Эпителиоретикулоциты мозгового вещества располагаются по отдельности или образуют небольшие скопления. Цитоплазматические отростки WGA ${ }^{+}$эпителиоретикулоцитов мозгового вещества формируют крупнопетлистую сеть.

На четвертом часу постнатальной жизни наблюдается усиление интенсивности окраски отростков эпителиоретикулоцитов, формирующих мелкопетлистую сеть коркового вещества, это явление совпадает со значительным увеличением содержания гибнущих лимфоцитов коры. В мозговом веществе встречается большое количество эпителиоретикулоцитов с эндоцитоплазматическим расположением рецепторов к лектину завязей пшеницы. Через 12 часов после рождения в мозговом веществе визуализируется хорошо выраженная крупнопетлистая $\mathrm{WGA}^{+}$-сеть, наблюдается увеличение содержания $\mathrm{WGA}^{+}$-клеток (рис. 1), удельная плотность распределения бензидиновой метки к этому лектину увеличивается.

Наряду с этим отмечается усиление процессов эмиграции лимфоцитов из тимуса на периферию, подтверждаемое развитием физиологического отека и уменьшением лимфоэпителиального отношения (рис. 2). 


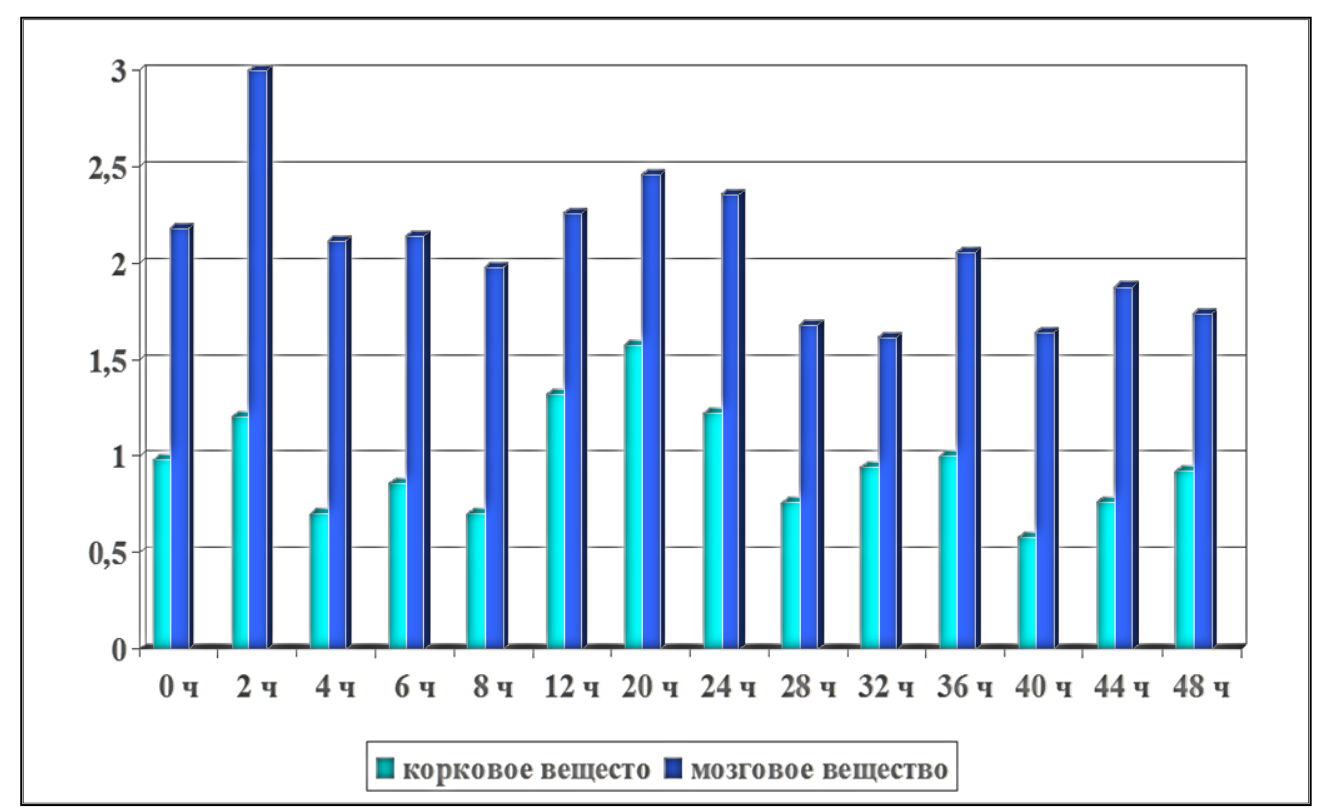

Рис. 1. Динамика содержания $W_{G}^{+}$клеток в корковом и мозговом веществе тимуса новорожденных крыс

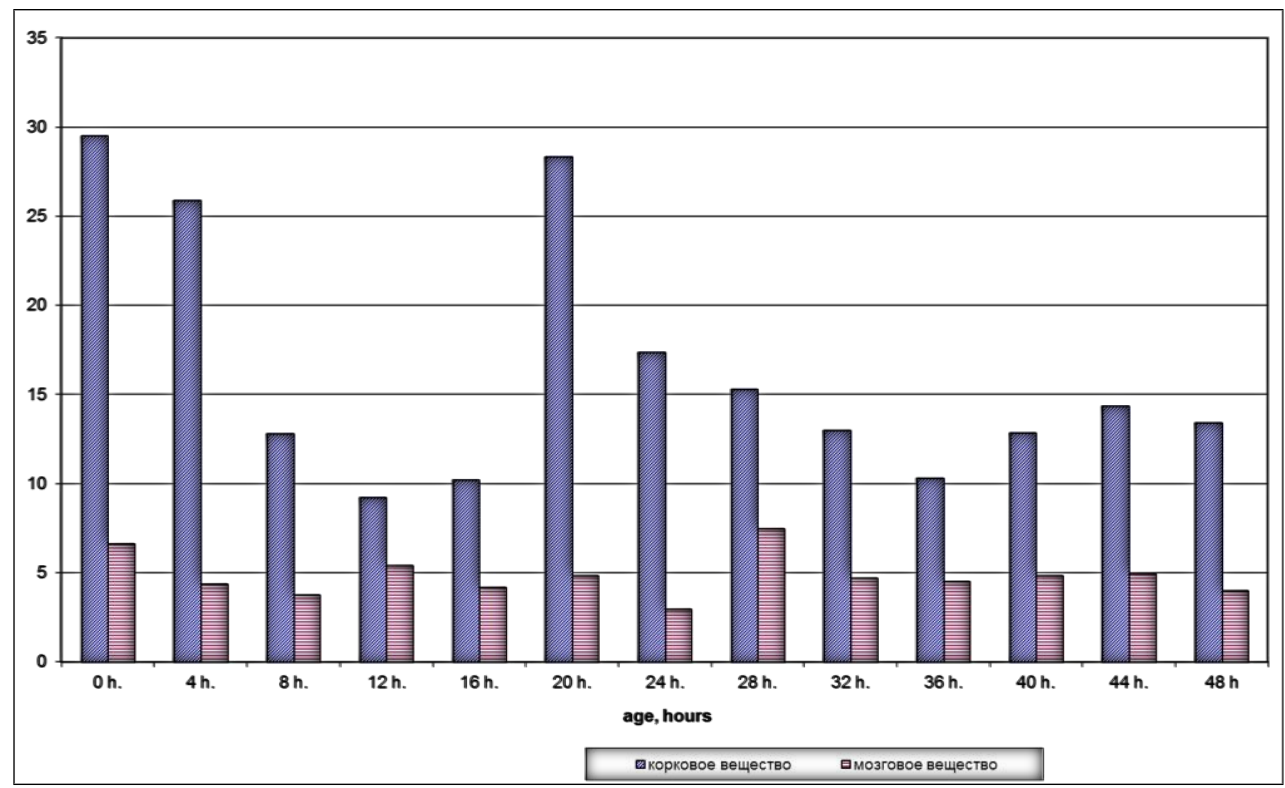

Рис. 2. Динамика лимфоцичто-эпителиального индекса в корковом и мозговом веществе тимуса новорожденHolx крыс

A. Varas (2000) и др. указывали на выход незрелых лимфоцитов из тимуса новорожденных [5]. По их данным, миграционная активность лимфоцитов новорожденных стимулируется высокой концентрацией гликопротеидов экстрацеллюлярного матрикса, особенно фибронектина мозгового вещества. В дальнейшем, до конца срока наблюдения определяется периодическое изменение интенсивности распределения рецепторов к лектину завязи пшеницы в цитоплазме эпителиоретикулоцитов коркового и мозгового вещества тимуса, что свидетельствует о периодичности процессов пролиферации, дифференцировки и миграции лимфоцитов.
Выводы. 1. Содержание WGA+ - эпителиоретикулоцитов коры и мозгового вещества динамически изменяется в течение всего периода наблюдения. Максимальное содержание WGA+ эпителиоретикулоцитов в коре $(1,58 \pm 0,3)$ выявлено на 20 -м часу, в мозговом веществе $(3 \pm 0,33)$ на 2-м часу постнатальной жизни. 2. В течение первой недели жизни изменяется плотность распределения рецепторов к лектину завязи пшеницы (WGA) на мембранах и в цитоплазме эпителиоретикулоцитов тимуса. Максимальная удельная плотность распределения рецепторов отмечена на 2-м часу раннего постнатального периода онтогенеза. 
Перспективы дальнейших исследований. В дальнейшем будет произведено изучение распределения рецепторов к лектинам конканава- лина А, бузины черной, вики посевной на структурах тимуса новорожденных крыс на фоне изменений в системе мать-плацента-плод.

\section{Список использованной литературы}

1. Alexandropoulos $K$. Thymic epithelial cells: antigen presenting cells that regulate $T$ cell repertoire and tolerance development / K. Alexandropoulos, N.M. Danzl // Immunol. Res. - 2012. - № 54 (1-3). - P. 177-90. doi: 10.1007/s12026-012-8301-y. 2. Perillo N.L. Galectin-1, an endogenouse lectin produced by thymic epithelial cells, induces apoptosis of human thymocytes / N.L. Perillo, C.H. Uittenbogaart, J.T. Nguyen // J. Exp. Med. - 1997. - V. 185, № 10. - P. 1851-1858. 3. Baum L.G. Characterization of terminal sialic acid linkages on human thymocytes: correlation between lectin-binding phenotype and sialtransferase expression / L.G. Baum, K. Derbin, N.L. Perillo // J. Biol. Chem. - 1996. - V. 271, N 3. - P. 10793-10799. 4. Barnes Y.C. Sialylation of the sialic acid binding lectin sialoadhesin regulates its ability to mediate cell adhesion / Y.C. Barnes, T.P. Skelton, I. Stamencovic // Blood. - 1999. - V. 93, № 4. - P. 1245-1252. 5. Varas A. Analysis of the human neonatal thymus: evidence for a transient involution. / A. Varas, E. Jimenes, R. Sacedon // J. Immunology. - 2000. - V. 164. - P. 6260-6267.

\section{ИСПОЛЬЗОВАНИЕ ЛЕКТИНОВОЙ ГИСТО- ХИМИИИ ДЛЯ ИЗУЧЕНИЯ МОРФОЛОГИИ ЭПИТЕЛИОРЕТИКУЛОЦИТОВ ТИМУСА}

Резюме. В работе изучено распределение WGA+эпителиоретикулоцитов в корковом и мозговом веществе тимуса новорожденных крыс. Установлено, что содержание WGA+ - эпителиоретикулоцитов коркового и мозгового вещества динамически изменяется в течение всего периода наблюдения. Максимальное содержание WGA+ - эпителиоретикулоцитов в корковом веществе $(1,58 \pm 0,3$ клетки на усл. ед. пл.) выявлено на 20-м часу, в мозговом веществе $(3 \pm 0,33$ клетки на усл. ед. пл.) - на 2-м часу постнатальной жизни. В течение первой недели жизни изменяется плотность распределения рецепторов к лектину завязи пшеницы (WGA) на мембранах и в цитоплазме эпителиоретикулоцитов тимуса. Максимальная плотность распределения рецепторов отмечена на 2-м часу раннего постнатального периода онтогенеза. Ключевые слова: тимус, эпителиоретикулоциты, корковое вещество, мозговое вещество, лектин завязи пшеницы.

\section{LECTINHISTOCHEMISTRY IN EXAMINA- TION OF THYMUS EPITHELIORETICULO- CYTES' MORPHOLOGY}

Abstract. Distribution of WGAt-epithelioreticulocytes in the cortex and medulla of the thymus of newborn rats was studied in the work. The content of WGA+-epitelioreticulocytes of the cortex and medulla changes dynamically during the whole period of examination. Maximal content of WGA+ epitelioreticulocytes in the cortex is found on the 20th hour, in the medulla - on the 2 nd hour of the postnatal life. During the first week of life the receptor distribution density to WGA changes on the membranes and cytoplasm of epithelioreticulocytes of the thymus. Maximal density of receptor distribution is found on the 2nd hour of early postnatal period of ontogenesis.

Key words: thymus, epithelioreticulocytes, cortex, medulla, Wheat Germ agglutinin.

Zaporozhye State Medical University (Zaporozhye)

Надійшла 19.01.2016 p.

Рецензент - проф. Олійник І.Ю. (Чернівці) 